\title{
Refletindo sobre Algumas Experiências na Oficina de Música
}

\section{Profeson Cordenacora VWane Beineke Aunas Bobistas. Cristine de Bortol \\ Shanakaht}

A "Oficina de Música" está sendo realizada com um grupo de crianças de oito e nove anos de idade, que estudam em colégios da rede pública, e que tiveram acesso ao programa NUPEART, através de uma divulgação feita nas escolas estaduais e municipais próximas à Universidade. Dos interessados que se matricularam, onze estão cursando a oficina de música. Até o presente momento foram desenvolvidas cinco aulas, as quais serão relatadas a seguir. As aulas são ministradas no "Laboratório de Ensino em Educação Musical", no Bloco da Música - CEART/UDESC, espaço este equipado com uma variedade de instrumentos de percussão de som definido e indefinido, flautas doces e uma aparelhagem de som.

Iniciamos a primeira aula da oficina com uma atividade de apreciação, na qual os alunos ouviram uma peça do compositor e educador musical Carl Orff, a qual logo foi reconhecida pelas crianças, que a associaram a propagandas veiculadas na mídia. Essa música foi selecionada porque na atividade seguinte foi proposta a execução de uma pequena peça para instrumentos de percussão do mesmo autor. Nesse momento também foram apresentados alguns instrumentos musicais para os alunos, tais como a flauta doce, xilofones, metalofones e outros instrumentos de percussão. Esses instrumentos foram explorados pelas crianças e são utilizados em todas as aulas nas atividades de execução e composição. A música trabalhada na seqüência - o Blues do Mosquito, uma canção com acompanhamento de palmas, voz e piano - foi bem recebida por todos. 
$\mathrm{Na}$ segunda aula, deu-se continuidade aos trabalhos com os instrumentos, visando que os alunos tivessem maior domínio no manuseio e conhecimento dos mesmos. Essa atividade procurou desenvolver também a percepção através de atividades de imitação e jogo rítmico. A música apresentada na aula anterior foi retomada, mas o arranjo da mesma foi mais sofisticado, acrescentando-se outros instrumentos. Cada criança escolheu o instrumento que desejava tocar e elaborou uma maneira própria de tocá-lo juntamente com as palmas. Foram trabalhados elementos expressivos na interpretação da música, sendo exploradas diferentes maneiras de executá-la, com variações de dinâmica e andamento.

Nesta mesma aula, os alunos foram divididos em três grupos, sendo que cada grupo ensaiou e elaborou um arranjo para o Blues do Mosquito, apresentando o resultado para seus colegas. Essas apresentações foram gravadas em fita de áudio, e no final todos ouviram com entusiasmo suas gravações. Finalizando a aula, apresentamos uma nova música às crianças, uma cançâo do folclore japonês chamada O Kina Kuri No, a qual gerou um interesse e curiosidade imediatas pelo significado da letra.

A terceira aula iniciou com uma atividade que foi chamada "cabine dos sons". Em forma de jogo, os instrumentos conhecidos pelos alunos ficavam escondidos e uma das professoras os tocava enquanto a outra fazia perguntas do tipo: que instrumento estava sendo tocado, de que material era feito e como o som era produzido. Os alunos se sentiram desafiados com a atividade, memorizando o nome e as características dos instrumentos.

A música $O$ Kina Kuri No foi relembrada e os alunos receberam a partitura da mesma, para ir se familiarizando com os códigos da escrita musical. A seguir, as crianças foram divididas em dois grupos, 
sendo cada grupo orientado por uma professora, para a execução de um arranjo a várias vozes. A parte de cada criança foi trabalhada por imitação: a professora tocando e o aluno memorizando a sua parte. Depois cada grupo apresentou seu trabalho para o outro.

A quarta aula iniciou com a apresentação do "quadro de repertório" para as crianças, anotando-se as músicas que já haviam sido trabalhadas e sendo explicado que cada nova peça iria sendo acrescentada naquela listagem. Também foi explicado aos alunos que pretendia-se apresentar e gravar este repertório no final do semestre, o que causou uma certa expectativa por parte dos alunos. Os alunos foram então convidados a tocar a primeira música do repertório, o Blues do Mosquito, definindo-se também os instrumentos que cada um iria executar, destacando-se a responsabilidade de cada criança em "tocar a sua parte" da música.

Posteriormente, foi proposta uma atividade de composição instrumental utilizando a escala pentatônica, que é a mesma da canção japonesa. Para isto, os alunos foram divididos em dois grupos e cada grupo apresentou sua composição para o outro, sendo a apresentação gravada em fita cassete e analisadas as composições. Em seguida, foram convidados a ouvir uma gravação em CD da música O Kina Kuri No, tocada pelos alunos da Escola Rosa de Lima, de Porto Alegre. Então elas comentaram o que tinham percebido e depois definiu-se os instrumentos que eles iriam tocar nesta peça.

No início da quinta aula as crianças ficaram em silêncio repentinamente, e lhes foi perguntado se elas achavam que o silêncio poderia ser considerado música ou não. A princípio, todas falaram que não, mas então tocou-se um trecho de uma música que tinha pausas e elas rapidamente mudaram de opinião e falaram que o silêncio faz parte da música, da mesma forma que os 
sons. Aproveitou-se a ocasião para introduzir o conceito de pausa e mostrar alguns símbolos musicais utilizados para representá-la na partitura.

Nesta aula também foi apresentada uma música nova, chamada Índio Lindo, de Thelma Chan, que coincidentemente tem várias pausas. Então foi escrita a escala diatônica de dó maior (dó, ré, mi, fá, sol, lá, si) no quadro e as crianças cantaram a escala com o auxílio do piano. Depois foram circuladas somente as notas usadas nessa canção, separando-as das demais e solfejando o nome das notas com suas respectivas alturas. Em seguida, foi proposta a elaboração de um arranjo instrumental em grupos. As crianças receberam a partitura para poderem ler a letra, e observamos que elas estavam tentando entender o que estava escrito e algumas crianças fizeram anotações nas partes em que havia pausas escritas. No final da aula, um grupo apresentou para o outro o seu trabalho e depois explicaram para os colegas como haviam pensado o seu arranjo.

Nesta seqüência de aulas, já foi possível observar um grande desenvolvimento musical por parte dos alunos. Quando se trata de apreciação, percebe-se uma percepção bem mais abrangente dos elementos musicais presentes na músicas, passando da percepção de quais instrumentos estão sendo utilizados à percepção de elementos relativos ao caráter expressivo.

Já a execução das peças está cada vez mais rica, pois além deles terem maior domínio técnico dos instrumentos, também estão realizando variações de dinâmica, mudanças de andamento e analisando os resultados obtidos. Os alunos mostram-se cada vez mais interessados em aprender música - tocando, cantando, compondo e analisando - além do interesse que vem manisfestando em aprender a ler e escrever música. Observamos que as crianças estão percebendo 
as funções e a importância do registro musical nos trabalhos de composição e arranjo como, por exemplo, quando sentiram a necessidade de fazer anotações nas partituras para organizar melhor o seu pensamento musical. Aconteceu também de um aluno vir perguntar para a professora sobre as notas da partitura e, depois de localizá-las no piano e na partitura, conseguiu tocar a melodia das músicas não apenas no piano, como também no xilofone e metalofone, usando como referência não apenas o ouvido, como também a escrita musical.

Relacionando os pressupostos teóricometodológicos que fundamentam a Oficina de Música com o trabalho que estamos desenvolvendo, percebemos que é possível aproximar os alunos de diferentes tipos de música; que a escrita musical pode ser aprendida na própria realização musical, sem fazer uso das tradicionais aulas de teoria e solfejo; que o tipo de atividades propostas, nas quais cada criança tem um papel a cumprir nas músicas trabalhadas, estabelece um comprometimento das crianças com a aula - elas sabem que se faltarem a aula, a música ficará "incompleta"; a realização de trabalhos em pequenos grupos também consistiu em um importante recurso pedagógico, à medida que propiciava a troca de experiências entre os próprios alunos.

No processo de planejamento e ação pedagógica, percebemos que a integração entre as atividades de apreciação, execução e composição dão unidade à proposta, constituindo o seu fio condutor, e que isto também provoca um engajamento dos alunos, que percebem a coerência e articulação entre todas as atividades desenvolvidas. 